\title{
Identification of a gene that makes a protein by using a cell free protein synthesis system
}

\begin{abstract}
A living cell could be genetically modified to perform a function such as the production of a protein. However, these genetic modifications often conflict with normal cellular function and result in a mutation. Defects can be overcome through removing the bacterial membrane which leaves the lysate that is performing both transcription and translation. The cell free-protein synthesis is also known as in vitro protein synthesis and is the production of a protein without using a living cell. The gene is acting as instructions to make the protein. If we can isolate a gene and then apply a cell free protein synthesis system after synthesis the protein and run on gel-electrophoresis we can identify a gene on the basis of the protein. Gel electrophoresis is a laboratory technique used to proteins according to molecular size and charge.
\end{abstract}

Volume 8 Issue 4 - 202I

\author{
Umair Masood \\ State University of New York, USA
}

Correspondence: Umair Masood, State University of New York, USA, Email umairawan0505@gmail.com

Received: July 29, 2021 | Published: August 24, 2021

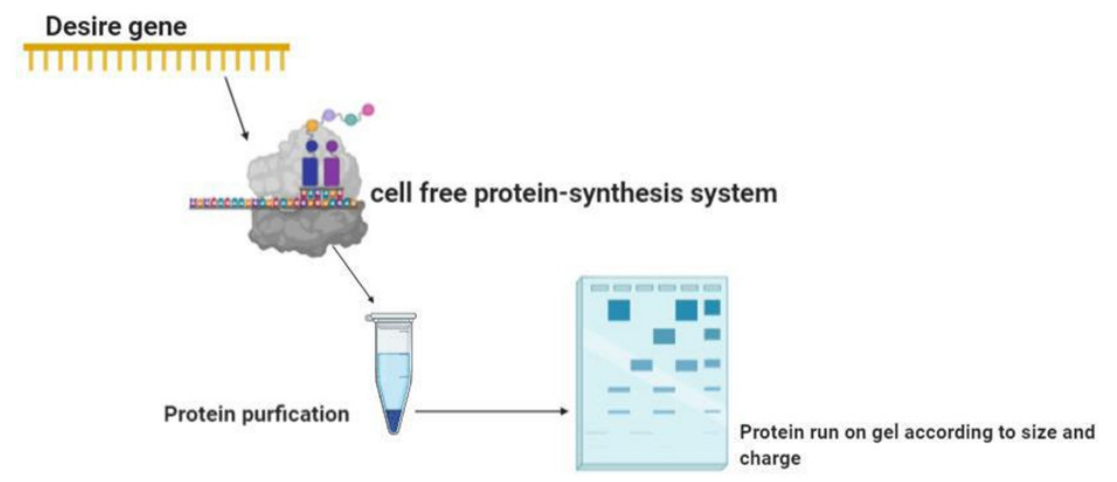

\section{Steps of identifying gene}

a. Isolation of gene: Gene can be isolated from different method but we can preferer a amplify a desire gene by using PCR method PCR is a method broadly used in molecular biology to manufacture several copies of a specific DNA segment. Permit scientist to take a very small sample of DNA and amplify it to a huge enough amount to study in detail. The basic principle of PCR is based on thermocycler. ${ }^{1-4}$ There are three main steps of PCR: Denaturation, Annealing, Extension.

b. Cell free system: development of cell free system is your choice you can either break the wall of bacteria and make a cell free system or order a different kit which is available in online websites. c. Purification of protein: there are different types of technique we can be used mainly are centrifuge method dialysis and chromatography.

d. Run on gel: after purify a protein, protein run on the gel we can identify a protein by using their molecular size. If we can identify a protein, we can identify a gene on the bases of protein.

\section{Result}

Protein blends in the dialysis framework. (A and B) Coomassie blue-stained SDS polyacrylamide gels showing DHFR blend with (A) or without (B) expansion of new mRNA. Bolts and indicators mark DHFR and creatine kinase, individually. The standard example was ready by blending a response combination without mRNA with known measures of DHFR prior to stacking onto the gel.

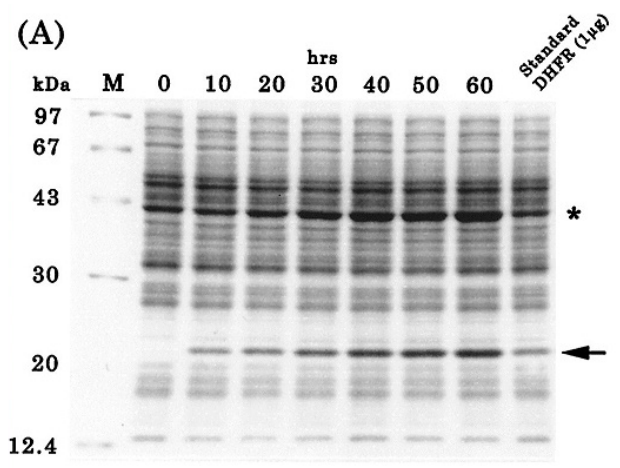

(B)

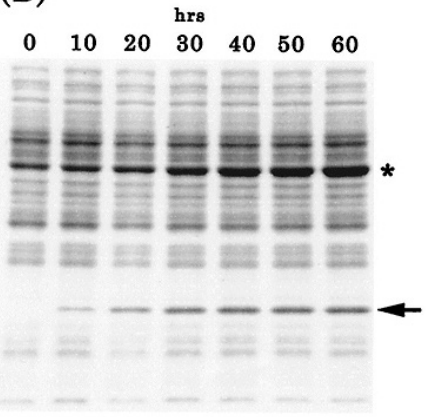




\section{Acknowledgments}

None.

\section{Conflicts of interest}

The author declares that there is no conflict of interest.

\section{Funding}

None.

\section{References}

1. Gregorio Nicole E, Levine Max Z, Oza Javin P. A User's Guide to CellFree Protein Synthesis. Methods and Protocols. 2019;2(1):24.
2. Saiki RK, Scharf S, Faloona F, et al. Enzymatic amplification of betaglobin genomic sequences and restriction site analysis for diagnosis of sickle cell anemia. Science. 1985;30(4732):1350-1354.

3. Tinafar Aidan, Jaenes Katariina, Pardee Keith. Synthetic Biology Goes Cell-Free. BMC Biology. 2019;17 (1).

4. Newton CR, Graham A, Heptinstall LE, et al. Analysis of any point mutation in DNA. The amplification refractory mutation system (ARMS) Nucleic Acids Research. 1989;17 (7):2503-2516. 